http://dx.doi.org/10.5597/lajam00156

\title{
INITIAL DESCRIPTION OF MAJOR HistocompatibILITY COMPLEX VARIATION AT TWO Class II LOCI (DQA-DQB) IN Sotalia FLUVIATILIS AND SOTALIA GUIANENSIS
}

\author{
Susana Caballero ${ }^{1,2, *}$, Dorothea Heimeier ${ }^{1}$, Fernando Trujlllo ${ }^{3}$, Juliana A. Vianna ${ }^{4,5}$, \\ Héctor Barrios-Garrido ${ }^{6}$, Maria G. Montiel 7 , Sandra Beltrán-Pedreroso ${ }^{8}$, Miriam Marmontel ${ }^{9}$, \\ Marcos C. de O. Santos ${ }^{10}$, Marcos R. Rossi-Santos ${ }^{11}$, Fabricio R. Santos ${ }^{4}$ and C. Scott Baker ${ }^{1,12}$
}

\begin{abstract}
АвтRACт: Genes of the major histocompatibility complex (MHC) play a key role in the initiation of immune response in jawed vertebrates. Variation at MHC loci can be used as an indicator of the genetic 'health' of natural populations and offer insight into potential susceptibility to epizootics. Here we present the first characterization of the sequence variation at two MHC class II loci (DQA and DQB) in the neotropical coastal (Sotalia guianensis) and riverine (Sotalia fluviatilis) dolphins, using cloning and direct sequencing of amplified genomic DNA. Four DQA and four DQB alleles were identified in 33 and 32 Sotalia samples, respectively, and high nucleotide diversity among these alleles was detected, similar to the findings described for other cetacean species. Positive selection was evidenced by an excess of $d_{n} / d_{s}$ at the PeptideBinding-Region of the DQB of Sotalia. The presence of common alleles at both loci in S. fluviatilis and S. guianensis are consistent with trans-species mode of evolution in the MHC. In contrast to observed low levels of mtDNA diversity at the population level, there was an apparent lack of reduction of DQA and DQB allelic variation in the Brazilian Coast population unit. This suggests either present or past balancing selection acting to maintain MHC variation in this population unit.

Resumen: Los genes del Complejo Mayor de Histocompatibilidad (MHC) juegan un papel primordial en la iniciación de la respuesta inmune en vertebrados mandibulados. La variabilidad en loci del MHC puede ser utilizada como un indicador de la 'salud' genética de poblaciones naturales y puede ayudar a determinar riesgos potenciales sobre su suceptibilidad a epidemias. Esta investigación representa la primera caracterización de la variabilidad genética en secuencias de dos loci de la Clase II (DQA y DQB) del MHC en los delfines neotropicales Sotalia guianensis y Sotalia fluviatilis, utilizando clonación y secuenciación directa de ADN genómico previamente amplificado. Se identificaron cuatro alelos para DQA y cuatro para DQB en 33 y 32 muestras de Sotalia, respectivamente. Se determinó alta diversidad nucleotídica en estos alelos, resultado similar a los datos publicados previamente para otras especies de cetáceos. Se evidenció selección positiva por el exceso en el $d_{n} / d_{s}$ en la Región de Unión de péptidos del locus DQB en Sotalia. La presencia de alelos communes entre $S$. fluviatilis y $S$. guianensis es consistente con el modelo de evolución transespecífico del MHC. En contraste con los bajos niveles de diversidad genética en el ADN mitocondrial observados para la unidad poblacional de la Costa de Brasil, no se encontró una reducción aparente en la variación alélica en dicha unidad poblacional. Este resultado sugiere la acción de selección balanceadora presente o pasada actuando para mantener la variabilidad en el MHC en esta unidad poblacional.
\end{abstract}

KeYwords: Sotalia fluviatilis, Sotalia guianensis, MHC, balancing selection.

\footnotetext{
${ }^{1}$ Laboratory of Molecular Ecology and Evolution, School of Biological Sciences, The University of Auckland, Private Bag 92019, Auckland, New Zealand

${ }^{2}$ Laboratorio de Ecología Molecular de Vertebrados Acuáticos, Departamento de Ciencias Biológicas, Universidad de los Andes, Carrera 1 \# 18 A-10, Bogotá, Colombia

${ }^{3}$ Fundación Omacha, Diagonal 86A \# 30-38, Bogotá, Colombia

${ }^{4}$ Laboratório de Biodiversidade e Evolução Molecular, Departamento de Biologia Geral, ICB, Universidade Federal de Minas Gerais, Av. Antonio Carlos, 6627 C.P. 486, 31270-010 Belo Horizonte, MG, Brazil

${ }^{5}$ Departamento de Ecosistemas y Médio Ambiente, Facultad de Agronomía e Ingeniería Forestal, Pontifícia Universidad Católica de Chile, Av. Vicuña Mackenna 4860, San Joaquin, Santiago, Chile

${ }^{6}$ Laboratorio de Ecología General, Facultad Experimental de Ciencias, Universidad del Zulia, Av. Universidad con prolongación Av. 5 de Julio. Sector Grano de Oro, Maracaibo, Venezuela

${ }^{7}$ Laboratorio de Ecología y Genética de Poblaciones, Centro de Ecología, Instituto Venezolano de Investigaciones Científicas, San Antonio de los Altos, Carretera Panamericana km 11, Altos de Pipe, Estado Miranda, Venezuela

${ }^{8}$ Laboratório de Zoologia, Coleção Zoológica Paulo Burheim, Centro Universitario Luterano de Manaus, Manaus, AM, Brazil

${ }^{9}$ Instituto de Desenvolvimento Sustentável Mamirauá, Estrada do Bexiga 2584, Bairro Fonte Boa, 69470-000 Tefé, AM, Brazil

${ }^{10}$ Laboratório de Biologia da Conservação de Cetáceos, Programa de Pós-Graduação em Zoologia, Departamento de Zoologia, Instituto de Biociências, Universidade Estadual Paulista 'Júlio de Mesquita Filho', Campus Rio Claro, Av. 24-A, 1515, Bela Vista, Rio Claro, SP, Brasil, 13506-900

${ }^{11}$ Instituto Baleia Jubarte, Rua Barão do Rio Branco 26, 45900-000 Caravelas, BA, Brazil

${ }^{12}$ Marine Mammal Institute and Department of Fisheries and Wildlife, Hatfield Marine Science Center, Oregon State University, 2030

SE Marine Science Drive, Newport, Oregon 97365, USA

* Corresponding author, e-mail: sj.caballero26@uniandes.edu.co
} 


\section{Introduction}

Cell surface glycoproteins encoded by the Major Histocompatibility Complex (MHC) play a key role in the initiation of immune response in vertebrates, by binding foreign peptides and presenting them to T-cells (Hedrick, 1994). The class I molecules present peptide proteins from virus-infected or malignant cells, while the class II molecules present peptides that originate from foreign material such as bacteria or parasites (Klein, 1986). A distinctive feature of the MHC is the high level of polymorphism exhibited in the Protein Binding Region (PBR) of class I and class II loci in most mammals. This has been suggested as an adaptation to the large number of pathogens encountered by natural populations (Klein and Takahata, 1990). The Peptide Binding Region (PBR) of exon-2 is expressed in the $b$ chains of class II genes of most mammals (Brown et al., 1993) and has been postulated as being directly involved in the interaction and association of foreign peptides and their presentation to T-cells (Hedrick, 1994), showing a large amount of the functional allelic variation.

Comparison of the proportion of non-synonymous substitutions per non-synonymous site and the proportion of synonymous substitutions per synonymous site $\left(d_{r} / d_{s}\right)$ ratios of the PBR have provided evidence of positive (overdominant) selection in MHC loci (Hill et al., 1992). Overdominant selection through heterozygous advantage allows higher than expected levels of polymorphism to be maintained for longer periods of time at loci such as the MHC (Hughes and Nei, 1989), potentially increasing antigen recognition and presentation ability, providing, in theory, increased disease resistance (Potts and Slev, 1995; Penn et al., 2002). Balancing selection would operate in favor of increased allelic variation, making it possible for a species to have higher number of MHC alleles even if it has low or lacks variation at other neutral loci (Aguilar et al., 2004).

Given its role in immune response, $\mathrm{MHC}$ variation has been suggested as an indicator of genetic 'health' in natural populations. Populations that have undergone demographic and genetic bottlenecks may have reduced variation at this locus, and reduced or lack of variation at this locus in isolated populations may increase the risk of extinction of that particular population $\left(\mathrm{O}^{\prime}\right.$ Brien and Evermann, 1988; Yuhki and O'Brien, 1990; Ellegren et al., 1996; Seddon and Baverstock, 1999).

Previous studies on MHC variation in marine mammals, including cetaceans and most pinnipeds studied so far, have shown less polymorphism than in most terrestrial mammals (Trowsdale et al., 1989; Slade, 1992; Murray et al., 1995; Baker et al., 2006). This lower amount of MHC variation in marine mammals has been explained by a possible decrease in exposure to pathogens in the marine environment or an 'escape' from terrestrial pathogens (Slade, 1992), although all marine mammals studied to date show evidence of overdominant selection, and Yang et al. (2005), found high variation in the Yangtze River dolphin (Lipotes vexillifer).

The coastal and riverine forms of the neotropical dolphin Sotalia have been recently proposed and recognized as different species (Monteiro-Filho et al., 2002; Cunha et al., 2005; Caballero et al., 2007; Caballero et al., 2010 this volume). These species, Sotalia guianensis (coastal) and Sotalia fluviatilis (riverine), offer an interesting natural experiment in interaction with different pathogens occurring in marine and riverine environments and this makes them attractive species to study differences in MHC variation patterns under possibly different selection pressures (Møller, 1998; Bernatchez and Landry, 2003; Wegner et al., 2003). Sotalia dolphins are also an interesting model to assess the amount of genetic variation at MHC loci in different dolphin populations, as they occur close to human settlement, where human activities could increase habitat degradation, potentially increasing the sources of pathogens that could pose health risks to these dolphin populations (Monteiro-Neto et al., 2003; Schad et al., 2004; Yang et al., 2005).

Here we present a preliminary analysis and characterization of the amount of genetic variation at exon 2 of two MHC class II loci (DQA and DQB) in the neotropical dolphins of the genus Sotalia, using cloning and direct sequencing. We first analyze the level of sequence variation within the DQA and DQB alleles determined in these species and then compare the level of genetic variation determined for DQB in other cetacean species. We then determine allelic variation at the DQA and DQB loci between coastal and riverine Sotalia and among population units of Sotalia fluviatilis and Sotalia guianensis.

\section{Material and Methods}

\section{SAMPle COLlECtiON AND DNA EXTRACTION}

A total of 37 skin samples were obtained from $S$. fluviatilis and S. guianensis in twelve locations grouped into seven geographic regions throughout their range (Table 1, Figure 1). Tissue samples were obtained from dead stranded animals or animals captured in fishing nets with the exception of a set of samples from the Colombian Caribbean, four of which were obtained from captive animals and two from free-ranging dolphins. Samples from captive animals were obtained by removing a small piece of skin from the tail. Skin from free ranging animals was collected using a small dart deployed from a modified veterinary capture rifle (Krützen et al., 2002). Skin samples were stored in $70 \%$ ethanol at $-20^{\circ} \mathrm{C}$. DNA extraction from tissue samples followed the protocol of Sambrook et al. (1989), modified for small samples by Baker et al., (1994). Samples collected in Brazil $(n=18)$ were analyzed at the Universidade Federal de Minas Gerais (UFMG) in Belo Horizonte, Brazil. 
Table 1. Geographic region, sampling location, population unit (determined from the SAMOVA, Caballero et al. 2010), habitat and sample size for Sotalia guianensis and Sotalia fluviatilis samples included in this analysis.

\begin{tabular}{|c|c|c|c|c|}
\hline GEOGRAPHIC REGION & SAMPLING LOCATION & HABITAT & $\begin{array}{c}\text { SAMPLE SIZE AND } \\
\text { TYPE }\end{array}$ & POPULATION UNIT \\
\hline \multicolumn{5}{|l|}{ Sotalia guianensis } \\
\hline \multirow[t]{3}{*}{ Colombian Caribbean } & $\begin{array}{l}\text { (1) Morrosquillo Gulf } \\
\text { (Córdoba province) }\end{array}$ & Coastal-estuarine & 4 skins & i (NSA) \\
\hline & $\begin{array}{l}\text { (2) Santa Marta } \\
\text { (Magdalena province) }\end{array}$ & Coastal-estuarine & 2 skins & i (NSA) \\
\hline & (3) La Guajira province & Coastal-estuarine & 4 skins & i (NSA) \\
\hline Maracaibo Lake & (4) Zapara Island & Coastal-estuarine & 2 skins & $\mathrm{i}(\mathrm{NSA})$ \\
\hline French Guiana & (5) Cayenne & Coastal-estuarine & 4 skins & ii (FG) \\
\hline \multirow[t]{5}{*}{ Brazilian Coast } & (6) Bahia state & Coastal-estuarine & 1 skin & iv (BC) \\
\hline & (7) Espírito Santo state & Coastal-estuarine & 1 skin & iv $(B C)$ \\
\hline & (8) Rio de Janeiro state & Coastal-estuarine & 2 skins & iv $(B C)$ \\
\hline & $\begin{array}{l}\text { (9) Cananéia estuary } \\
\text { (São Paulo state) }\end{array}$ & Coastal-estuarine & 8 skins & iv (BC) \\
\hline & unknown & Coastal-estuarine & 1 DNA sample** & iv (BC) \\
\hline \multicolumn{5}{|l|}{ Sotalia fluviatilis } \\
\hline Peruvian Amazon & (10) Curaray River & Riverine & 1 skin & 1 (WA) \\
\hline Colombian Amazon & $\begin{array}{l}\text { (11) Puerto Nariño } \\
\text { (Amazonas province) }\end{array}$ & Riverine & 2 skins & $2(\mathrm{WA})$ \\
\hline Brazilian Amazon & $\begin{array}{l}\text { (12) Tefé } \\
\text { (Amazonas state) }\end{array}$ & Riverine & 5 skins & 3 (EA) \\
\hline
\end{tabular}

Numbers in parenthesis before each sampling location correspond to the number of this sampling location in Figure 1. Numbers defining population units are as follow for Sotalia guianensis: i) Northern South America (NSA), ii) French Guiana (FG) and iv) Brazilian Coast (BC). For Sotalia fluviatilis: 1) Western Amazon (WA) and 3) Eastern Amazon (EA). **Sample donated by the SWFSC: Southwest Fisheries Science Center (La Jolla, CA, U.S.A)

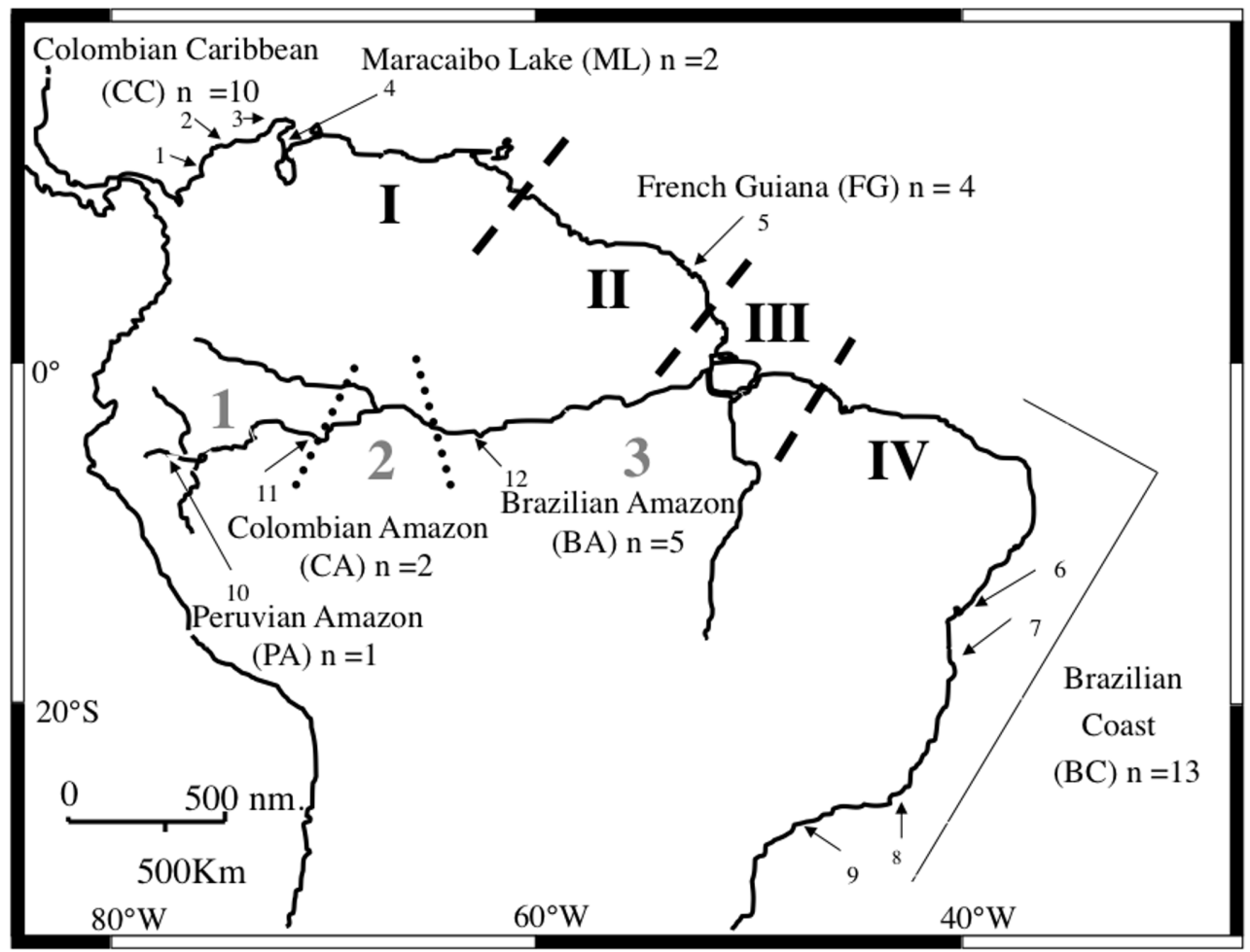

Figure 1. Geographic regions and sampling locations of Sotalia guianensis and Sotalia fluviatilis samples included in this analysis. Numbers correspond to sampling locations in Table 1. Also, we indicate the proposed genetic boundaries between Sotalia guianensis and Sotalia fluviatilis population units from the SAMOVA analysis (Caballero et al. 2010, this volume). Four units for the coastal species (dashed line, black numbers): I= Northern South America (Colombian Caribbean + Maracaibo Lake), II= French Guiana, III= Amazonian Estuary and IV= Brazilian Coast. Three units for the riverine species (dotted line, grey numbers): $1=$ Western Amazon, $2=$ Central Amazon, $3=$ Eastern Amazon. 


\section{PCR AMPLIFICATION}

Two class II MHC loci were amplified and analyzed in this study: 822bp spanning part of the exon-2 and exon-3 and all of intron- 2 of DQA and $171 \mathrm{bp}$ of the exon-2 region of DQB. Both loci were amplified via the Polymerase Chain Reaction (PCR) using standard reaction conditions (Saiki et al., 1988; Palumbi, 1996). For DQA exon-2 intron2 exon-3, the primer combination DQA-1 (5'CAGTACACCCATGAATTTGATGG-3') and DQA-2 (5'CCAGTGCTCCACCTTGCAGTC -3') (Auffray et al., 1987) was used. For DQB exon-2, the primer combination DQB-1 (5'- CTGGTAGTTGTGTCTGCACAC-3') and DQB-2 (5'-CATGTGCTACTTCACCAACGG-3') (Tsuji et al., 1992) was used. The final PCR reaction volume was $20 \mathrm{ml}$ and PlatinumTaq (Invitrogen) was used. The PCR profile for amplification of the DQA exon- 2 intron-2 exon3 was as follows: an initial denaturation at $94^{\circ} \mathrm{C}$ for $3 \mathrm{~min}$, 36 cycles at $94^{\circ} \mathrm{C}$ for $30 \mathrm{~s}, 58^{\circ} \mathrm{C}$ for $30 \mathrm{~s}$ and $72^{\circ} \mathrm{C}$ for $1 \mathrm{~min}$, and a final extension at $72^{\circ} \mathrm{C}$ for $10 \mathrm{~min}$. The PCR profile for amplification of the DQB exon-2 was as follows: an initial denaturation at $94^{\circ} \mathrm{C}$ for $3 \mathrm{~min}$, touchdown for 15 cycles at $94^{\circ} \mathrm{C}$ for $15 \mathrm{~s}, 64^{\circ} \mathrm{C}$ for $20 \mathrm{~s}$ (decreasing $1^{\circ} \mathrm{C}$ per cycle) and $72^{\circ} \mathrm{C}$ for 40 s followed by 30 cycles at $94^{\circ} \mathrm{C}$ for $15 \mathrm{~s}, 52^{\circ} \mathrm{C}$ for $20 \mathrm{~s}, 72^{\circ} \mathrm{C}$ for $40 \mathrm{~s}$, and a final extension at $72^{\circ} \mathrm{C}$ for $10 \mathrm{~min}$. Products of three independent successful amplifications were analyzed for each individual sample for each MHC locus.

\section{DIRECT SEQUENCING}

Products from three independent successful amplifications of genomic DNA were obtained from each individual sample for each MHC locus, including samples from all geographic locations. These were directly sequenced in both directions. Nucleotides and primers were removed from the PCR products using SAP (shrimp alkaline phosphatase) and ExoI (exonuclease I) (USB). PCR products were directly sequenced in both directions using the standard protocols of Big Dye ${ }^{\mathrm{TM}}$ terminator sequencing chemistry on an ABI 3100 automated capillary sequencer (Perkin Elmer). Samples analyzed at Universidade Federal de Minas Gerais (UFMG), were cleaned using 20\% PEG (Polyethyleneglycol) and directly sequenced using an ETDye terminator kit and run in a MegaBACE automated capillary sequencer (Amersham Biosciences).

\section{Cloning}

Amplified DQA from 13 samples, including six samples from the Colombian Caribbean, four samples from French Guiana, one sample from Maracaibo Lake and one sample from the Colombian Amazon and one sample from the Peruvian Amazon were cloned. Amplified DQB from ten samples, including six samples from the Colombian Caribbean and four samples from French Guiana were cloned. For all 23 samples, 40ng of amplified DNA was used in the ligation reaction with a pGEM-T cloning vector (Invitrogen) and $3 \mathrm{u} / \mathrm{ml}$ of $\mathrm{T} 4$
DNA ligase. Ligation reactions were incubated overnight at $4^{\circ} \mathrm{C}$ and cloned using high efficiency thermally competent cells. $100 \mathrm{ml}$ of transformed cells were cultivated in $\mathrm{LB}+\mathrm{amp} / \mathrm{Xgal}$ at $37^{\circ} \mathrm{C}$ overnight. Six colonies of each amplification product were re-amplified using the previously described amplification protocol. $4 \mathrm{ml}$ of the PCR product were run in a 1.6\% agarose gel in order to confirm the presence of insert. Between eight and 13 colonies were screened for the correct size insert and of these, three clones containing an insert of expected length were sequenced for each individual using M13 universal primers. Samples analyzed in Brazil were not cloned for either DQA or DQB due to logistic limitations, but at least 6 sequences from three independent amplifications were obtained for each individual for each locus (directly sequenced, three forward and three reverse). Overall, between three and eight complete sequences for each locus were obtained from each individual, including both clones and direct sequences in the case of the subset of samples previously described.

\section{SEQUENCE QUALITY AND NOMENCLATURE OF ALLELES}

Sequence quality was evaluated using the program Phred v.020425 (Ewing and Green, 1998; Ewing et al., 1998). Sequences with Phred scores d" 20 (a base call having a probability of more than $1 / 100$ of being incorrectly called) were excluded from the analysis and re-sequenced. Sequences with Phred score values between 20 and 40 (a probability between 1/100 and 1/ 10,000 of being incorrectly called) and sequences with Phred scores values ${ }^{3} 40$ were checked by eye to confirm variable sites, manually edited and aligned using Sequencher 4.1 software (Gene Codes Corporation). A variable or heterozygote site was indicated by a secondary peak ${ }^{3} 30 \%$ of the height of the primary peak, and by a local decline in the Phred score value. Heterozygotes were only considered to be authentic if they were observed in two or more sequences from a single individual. Single sporadic substitutions (not repeated) were considered misincorporations of nucleotides by the Taq polymerase (Taq errors) (Kobayashi et al., 1999). Identity of those positions was determined using the consensus of at least three sequences per individual. Identification of alleles was done by eye after genotypes of all individuals were compiled. Confirmation of locus identity was based on alignments with previously published DQB sequences for artiodactyl species (cow, Bos taurus) and other cetacean species, including finless porpoise (Neophocaena phocaenoides), harbor porpoise (Phocoena phocoena), Risso's dolphin (Grampus griseus), Irrawaddy dolphin (Orcaella brevirostris) (Hayashi et al., 2003), beluga (Delphinapterus leucas), narwhal (Monodon monoceros) (Murray et al., 1995; Murray et al., 1999), Antarctic minke whale (Balaenoptera bonaerensis) (Hayashi et al., 2003), right whale (Eubalaena glacialis) and humpback whale (Megaptera novaeangliae) (Baker et al., 2006). Unpublished short-finned and long-finned pilot whales (Globicepahala 
macrorhynchus and G. melas, respectively) DQB sequences were also included in this alignment. For DQA, confirmation of amplification and sequencing was performed by alignments with unpublished sequences from other cetacean species, including one dusky dolphin (Lagenorhynchus obscurus), one common bottlenose dolphin (Tursiops truncatus), long-finned pilot whales (G. melas), one short-finned pilot whale $(G$, macrorhynchus) and Hector's dolphins (Cephalorhynchus hectori) (Heimeier et al., 2009), sperm whale (Physeter macrocephalus), bowhead whale (Balaena mysticetus) and blue whale (Balaenoptera musculus) (C.S. Baker, unpublished data) and three beaked whale species, straptooth beaked whale (Mesoplodon layardii), Gervais' beaked whale (M. europaeus) and True's beaked whale (M. mirus) (Dalebout, 2002). DQB alleles of Sotalia were also compared by phylogenetic analysis of the $171 \mathrm{bp}$ alignment of the data generated in this study with previously published cetacean and artiodactyl sequences using the Neighbor-Joining method with the Kimura two-parameter model of evolution in MEGA3 (Kumar et al., 2004) (Figure 5). This phylogenetic reconstruction aimed at confirming identity of MHC loci and not as a true phylogeny of organisms. Lineage relationships within the DQA alleles determined for Sotalia were not investigated, due to lack of cetacean sequences for comparison. However, a phylogenetic reconstruction including 309bp of exon-2 and exon-3 DQA alleles determined in Sotalia as well as unpublished allele sequences from other cetaceans was conducted in MEGA3 using the Neighbor-Joining method with the Kimura two-parameter model of evolution (Figure 6). This phylogenetic reconstruction aimed at confirming identity of MHC loci and not as a true phylogeny of organisms. Sequence information of the DQA intron-2 was not included in the phylogenetic analysis as it was not available for species used as outgroups, cow and sheep (Ovis aries). Nomenclature of DQB alleles followed rules accepted in other species and sequence similarity (Klein et al., 1990): allele name is a four letter species code, a locus code, an asterisk (*) and a four digit allele code, e.g. MHC SoguDQB01*01, the first two numbers designating the allelic lineage and the last two the unique sequence (Murray et al., 1995). DQA alleles were named using a four-letter species code, a locus code and an allele number (Arabic).

\section{ANALYSIS OF ALLELIC VARIATION}

Pairwise sequence difference (average and range) was estimated among DQA and DQB alleles in MEGA3 using the Kimura two-parameter model and compared to other cetacean species. Identification of the peptidebinding region in the DQB exon-2 followed the description of the human HLA-DRB (Brown et al., 1993) or DQB applied to cetaceans following Murray et al. (1995). The proportion of synonymous nucleotide substitutions per synonymous site $\left(d_{s}\right)$ and the proportion of non-synonymous nucleotide substitutions per non-synonymous site $\left(d_{n}\right)$ was calculated in MEGA using the modified Nei and Gojobori method (Nei and Kumar, 2000). These calculations were performed independently for the whole sequence and for the codons outside and within the peptide-binding region. A Z-test (Nei and Kumar, 2000) was used to test for positive selection.

\section{SPECIES LEVEL AND POPULATION LEVEL ANALYSES}

Due to the small sample size included in this study, and due to the apparent presence of null alleles among the samples analyzed, we did not attempt a comprehensive statistical analysis of DQA and DQB allele frequencies. We suspected the presence of null alleles due to an excess of homozygous individuals in some particular populations units analyzed, creating an artificial Wahlund effect (Schad et al., 2004). Selective amplification of particular alleles over others is not uncommon with the use of 'universal primers' for MHC loci, although this has not been reported in the previous use of these primers for cetaceans (Auffray et al., 1987; Murray et al., 1995). Instead, we have restricted our analysis to the minimum number alleles in samples belonging to each of the two species considered in this analysis (Sotalia guianensis and Sotalia fluviatilis), as well as the distribution of different DQA and DQB alleles in the population units defined from a SAMOVA analysis of mtDNA in Caballero et al. (2010, this volume). The SAMOVA (Spatial analysis of Molecular Variance) was performed to evaluate genetic boundaries between the sampling locations studied (Dupanloup et al., 2002). The population units of Sotalia guianensis resulting from this analysis were i) Northern South America, grouping samples from sampling locations within the Colombian Caribbean and Maracaibo Lake (Venezuela) geographic regions, ii) French Guiana and iv) Brazilian Coast. For Sotalia fluviatilis, population units resulting from this analysis were: 1) Western Amazon, grouping most samples from the Colombian and Peruvian Amazon and 3) Eastern Amazon, grouping samples from the Brazilian Amazon.

\section{Results}

SEQUENCE ANALYSIS: ALLELIC DIVERSITY

For the DQA locus, 33 out of 37 Sotalia samples (seven riverine and 26 coastal) were successfully amplified for $828 \mathrm{bp}$. Among these 33 samples, four alleles were identified by the presence of seven variable sites (Table 2 ). Four variable sites were found in the exon-2, two variable sites were found in the intron- 2 and one additional variable site was found in the exon-3. 39 clones from 13 samples (3 clones per sample) were evaluated for the DQA locus and three DQA alleles were confirmed among these clones. Allele SoguDQA1 was detected in 14 clones from Colombian Caribbean samples $(n=5)$, three clones from Maracaibo Lake sample $(n=1)$, two clones of the French Guiana sample $(n=1)$, three clones 
from the Peruvian Amazon sample $(\mathrm{n}=1)$ and one clone from the Colombian Amazon sample $(n=1)$. The allele SoguDQA2 was detected in five Colombian Caribbean clones $(n=3)$ and one of the Colombian Amazon sample $(\mathrm{n}=1)$. Allele SoguDQA3 was detected in 10 clones from French Guiana samples $(n=4)$. The fourth allele
(SoguDQA4), found only in one sample from the Brazilian Coast population unit, was inferred by comparison of available genotypes and taking into account possible combinations of the three alleles directly observed. The deduced amino acid alignment of the four DQA alleles detected in Sotalia are presented in Figure 2.

Table 2. Seven variable sites detected along $918 \mathrm{bp}$ of the exon-2 intron-2 exon-3 of four DQA alleles in Sotalia. Nucleotide sequences were compared with sequences from other cetacean species (data not shown). Numbers indicate the nucleotide position with reference to the start of exon-2.

\begin{tabular}{lccc}
\hline \hline & & VARIABLE SITES & \\
\hline \hline & exon-2 & intron-2 & exon-3 \\
& 1122 & 23 & 3 \\
& 4901 & 82 & 9 \\
DQA Alleles & 9492 & 69 & \\
SoguDQA1 & & & A \\
SoguDQA2 & ATGC & GT & G \\
SoguDQA3 & GCAA & AG & G \\
SoguDQA4 & ACAC & AG & A \\
\hline \hline
\end{tabular}

\section{Translated DQA exon-2 intron-2 exon-3}

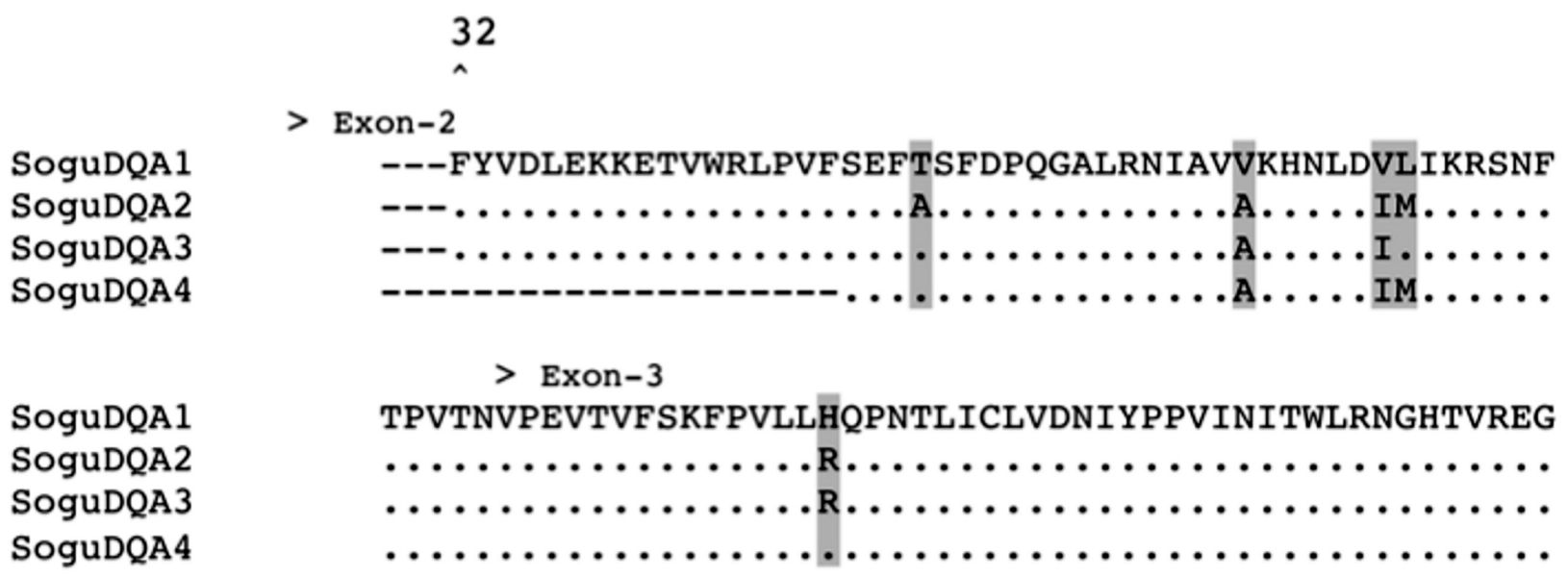

SoguDQA1
SoguDQA2
SoguDQA3
SoguDQA4

VSEISFLTKNDLSFLKISYLTFLPSDDD

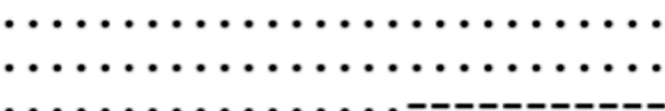

Figure 2. Deduced amino acid translation of DQA (exon-2 and exon-3). (>) indicates the start of the amino acid sequence coded by each exon and $(\wedge)$ at the start of the sequence represents position 32 of the amino acid sequence of exon-2. Grey shading denotes amino acid differences between alleles. 
For the DQB locus, 32 out of 37 Sotalia samples (seven riverine and 25 coastal) were successfully amplified for $171 \mathrm{bp}$. Within these 32 samples, four alleles were identified by the presence of 19 polymorphic sites (Figure 3). 30 clones from the subset of samples (3 clones per sample) were evaluated for the DQB locus and three alleles were confirmed from these clones. Allele SoguDQB01*01 was detected in 12 clones from French Guiana samples $(\mathrm{n}=4)$, Allele SoguDQB02*01 was detected in six clones from the Colombian Caribbean samples $(\mathrm{n}=2)$ and allele SoguDQB03*02 was found in 12 clones from the Colombian Caribbean samples $(\mathrm{n}=$ 4). The fourth allele (SoguDQB03*01) was determined from sequences obtained from four Brazilian Coast samples. The deduced amino acid alignments for the four DQB alleles detected in Sotalia are presented in Figure 4. No more than two alleles were detected per individual (considering clones and PCR products directly sequenced) therefore no evidence of duplication at this locus was detected for Sotalia. The four alleles seemed to belong to three allele lineages as observed in the phylogenetic reconstruction (Figure 5), two of them represented by only one allele (SoguDQB01*01 and SoguDQB02*01) and the third lineage represented by two alleles (SoguDQB03*01 and SoguDQB03*02). DQA and DQB allele sequences were submitted to Genbank as accession numbers FJ848537-FJ848544.

Among the four Sotalia DQA alleles, average difference was $0.5 \%$ and parwise sequence difference ranged from 0.03 to $0.09 \%$ (average $=0.05 \% \pm 0.002 \mathrm{SD}$ ). Average pairwise sequence difference among the four Sotalia DQB alleles was $6.7 \%$ ( $\pm 0.014 S D)$, similar to or slightly higher than the values calculated for other cetacean species (Table 3). Pairwise sequence divergence ranged from 1.2 to $9.3 \%$ and was similar to the sequence divergence values calculated for other cetacean species (Table 3), with alleles SoguDQB01*01 and $\operatorname{Sog} u \mathrm{DQB03}{ }^{*} 02$ being the most different and alleles SoguDQB03*01 and SoguDQB03*02 the least different.

DQB exon-2

\section{Exon-2}

46

46

SoguDQB $01 * 01$
SoguDQB 0 2*01
SoguDQB 0 3*01
SoguDQB 0 $3 * 02$

CACGGAGCGGGTGCGGCTCGTGACCAGACACATCTATAACCGGGAGGA

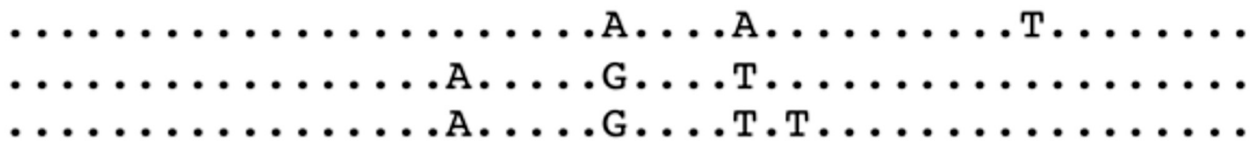

$\begin{array}{lllll}96 & 106 & 116 & 126 & 136\end{array}$

SoguDQB $01 * 01$

GTTCTTGCGCTTCGACAGCGACGTGGGCGAGTTCCGGGCGGTGACCGA

SoguDQB $02 * 01$

SoguDQB $03 * 01$

SoguDQB $03 * 02$
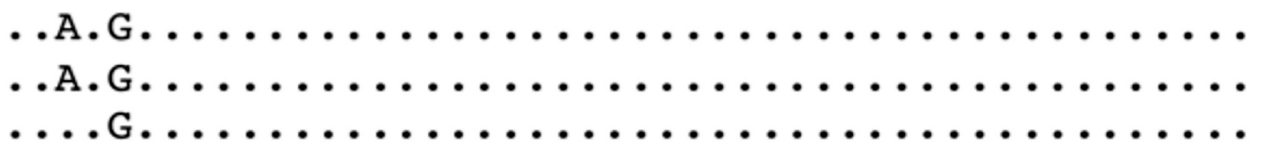

$\begin{array}{lllll}146 & 156 & 166 & 176 & 186\end{array}$

SoguDQB $01 * 01$

SoguDQB $02 * 01$

SoguDQB $03 * 01$

SoguDQB $03 * 02$

GCTGGGCCGACCGATCGCCAAGGACTTCAACAGCCAGAAGGACCTCCT

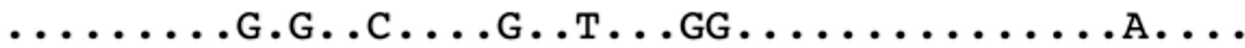

.........GA.........GG..............

.........GA.........GG...............

$196 \quad 206 \quad 216$

SoguDQB $01 * 01$

SoguDQB $02 * 01$

SoguDQB $03 * 01$

SoguDQB0 $3 * 02$

\section{GGAGCGGAAACGGGCCGAGCTGGACAC}

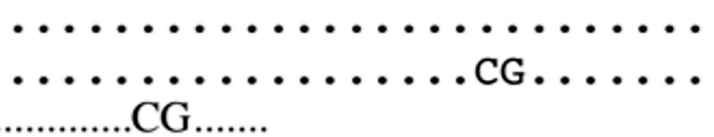

Figure 3. DNA sequence alignment for four alleles detected in the DQB (exon-2). Sequences were compared with sequences from other cetacean species (data not shown). Numbers and (') indicate the nucleotide position with reference to the start of exon-2. 


\section{Translated DQB exon-2}

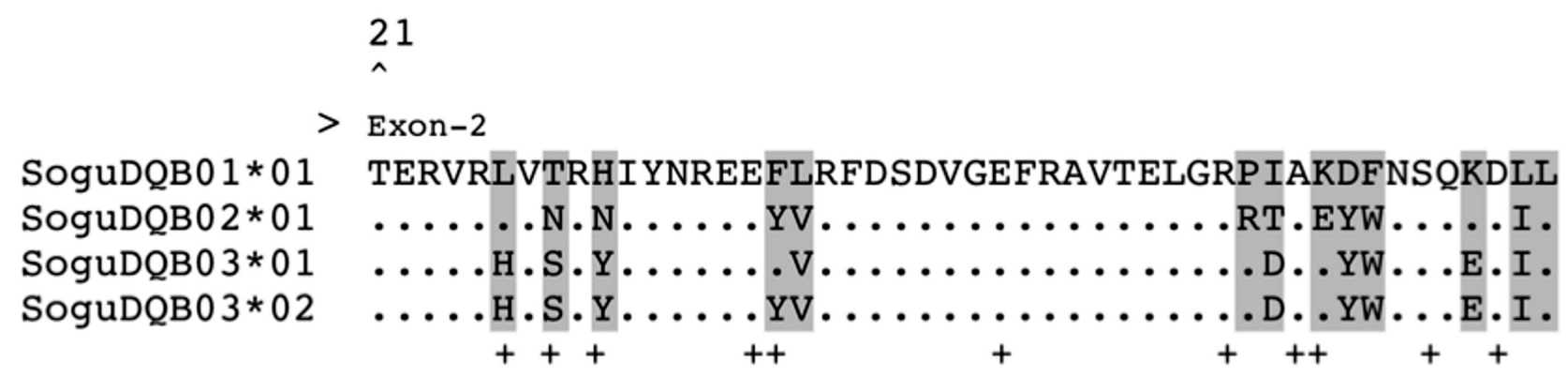

76

SoguDQB0 1*01
SoguDQB02 001
SoguDQB0 3*01
SoguDQB 0 3*02

ERKRAELD

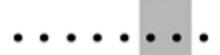

$\ldots \ldots$ DV.

.......DV.

$+++$

Figure 4. Deduced amino acid translation of DQB (exon-2). Numbers on top of the sequence correspond to the amino acid position based on the â chain of the DR structure (Brown et al., 1993). (>) indicates the start of the amino acid sequence coded by the exon- 2 . Grey shading denotes amino acid differences between the different alleles. Inferred peptide binding sites are indicated by the symbol $(+)$ below the sequence alignment (following Murray et al., 1995).

DQB exon-2 Peptide Binding Region (PBR) AND test of SELECTION

Among the four DQB alleles identified in Sotalia samples, variation was observed at ten out of 14 amino acid sites corresponding to the PBR (Figure 4). All sequences appear to be functional with no stop codons, insertions or deletions. The proportion of non-synonymous substitutions per non-synonymous sites $\left(d_{n}\right)$ was considerably higher than the proportion of synonymous substitutions per synonymous sites $\left(d_{s}\right)$ in the PBR but significantly higher when compared to the $d_{n}$ and $d_{s}$ calculated for the non-PBR and the whole sequence, respectively (Table 4 ).

For the DQB exon-2, the proportion of non-synonymous substitutions per non-synonymous sites compared to the proportion of synonymous substitutions per synonymous sites at the PBR was significantly higher, rejecting the null hypothesis of $d_{n}=d_{s}(\mathrm{z}=2.489, P=$ $0.007)$. The null hypothesis could not be rejected when it was tested for $171 \mathrm{bp}$ of the exon- 2 sequence $(z=1.563$, $P=0.060$ ) or for nucleotides coding for amino acids outside the PBR region $(z=1.027, P=0.382)$.

SPECIES AND POPULATION-LEVEL ANALYSES: DISTRIBUTION OF DQA AND DQB ALLELES BETWEEN SOTALIA GUIANENSIS AND SOTALIA FLUVIATILIS

Two DQA alleles (SoguDQA1 and SoguDQA2) were shared between samples obtained from riverine and coastal individuals, and no DQA allele was found exclusively in riverine samples, while two alleles (SoguDQA3 and
SoguDQA4) were found exclusively in coastal samples (Figure 6). Two DQB alleles (SoguDQB01*01 and SoguDQB03*02) were shared between samples obtained from riverine and coastal individuals, and no DQB allele was found exclusively in riverine samples, while two alleles (SoguDQB02*01 and SoguDQB03*01) were found exclusively in coastal samples (Figure 5).

Distribution of DQA AND DQB Alleles AMONG Sotalia POPULATION UNITS

For DQA, allele SoguDQA1 was found in samples belonging to all population units considered in this analysis. Allele SoguDQA2 was found in all population units excluding the French Guiana population unit (iiFG). Allele SoguDQA3 was detected only in samples from the French Guiana population unit (ii-FG) and in the Brazilian Coast population unit (iv-BC). The allele SoguDQA4 was detected only in the Brazilian Coast population unit (iv-BC) (Table 5). For DQB, allele SoguDQB01*01 was found in samples from the Northern South America population unit (i-NSA), the Western Amazon population unit (1-WA) and the Eastern Amazon population unit (3-EA). Allele SoguDQB02*01 was found in samples from the Northern South American population unit (i-NSA) and the Brazilian Coast population unit (iv$\mathrm{BC}$ ). Allele SoguDQA03*02 was found in samples from all population units excluding the French Guiana population unit (ii-FG) and allele SoguDQB03*02 was found only in one sample from the Brazilian Coast population unit (iv-BC) (Table 5). 


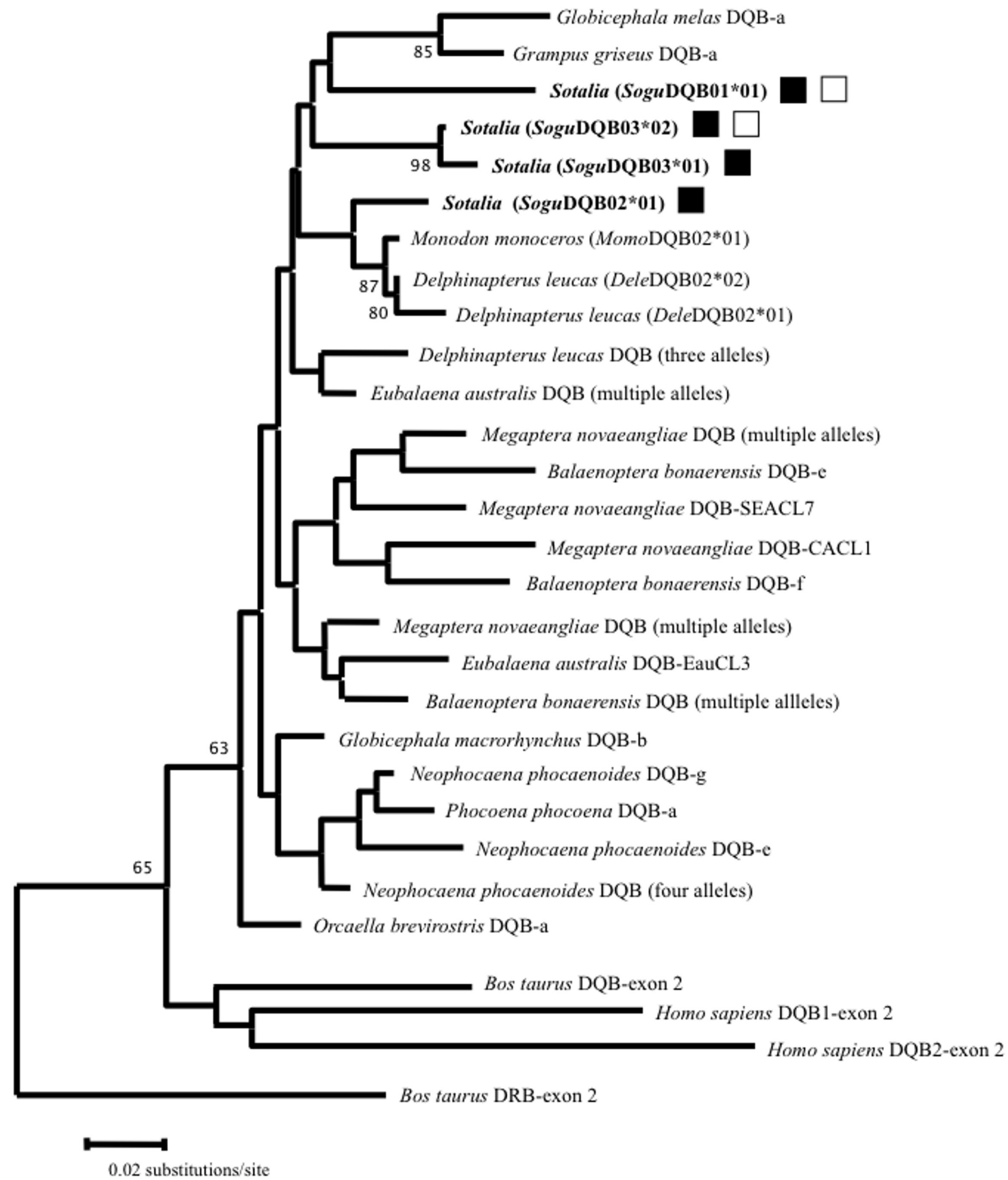

Figure 5. Neighbor-joining reconstruction of Sotalia and selected published (Baker et al., 2006) and unpublished (Dalebout, 2002; Heimeier et al., 2009) cetacean DQB exon-2 sequences. DRB exon-2 and DQB exon-2 sequences from cow (Bos taurus) and DQB exon-2 sequences from human (Homo sapiens) used as outgroups. Bootstrap support values (500 replicates) higher than 60 are shown below the branches. Sotalia alleles are shown in bold. A black square represents alleles found in Sotalia guianensis and a white square represents alleles found in Sotalia fluviatilis.

\section{Discussion}

\section{DQA-DQB POLYMORPHISM IN SOTALIA}

The level of MHC polymorphism and allelic variation at the DQB loci of Sotalia was similar to the level of polymorphism and allelic variation described in other cetaceans (Murray et al., 1995; Hayashi et al., 2003; Baker et al., 2006). Even though the number of DQB alleles found in Sotalia was lower than the number of alleles found in the finless porpoise (Hayashi et al., 2003; Hayashi et al., 2006), a species that shares similar body size, life history and habitat characteristics with Sotalia, average and range of pairwise sequence differences among DQB alleles was higher in Sotalia. Interestingly, the number of DQB alleles (4) identified in 33 Sotalia samples was similar to the number of DQB alleles (5) identified in 233 beluga whales, although the average 
and range of pairwise sequence differences among DQB alleles was higher for Sotalia.

Although there is no published information on the polymorphism and allele descriptions for the DQA locus in cetaceans to date, comparisons with unpublished and published cetacean data suggested similar levels of allelic variation and diversity (short-finned pilot whale, long-finned pilot whale, Hector's dolphin [Heimeier et al., 2009]). Other published data on DQA variation in marine mammals includes analysis of this loci in the northern elephant seal (Mirounga angustirostris) and four species of pinnipeds from Antarctica (Lehman et al., 2004).

Table 3. Number of alleles (with sample sizes), average and range of pairwise sequence differences among alleles (\%) \pm standard deviation (SD) (calculated in MEGA3), over 171bp of sequence length of DQB exon-2 alleles for various cetacean species.

\begin{tabular}{|c|c|c|c|c|c|}
\hline SPECIES & $\begin{array}{l}\text { SAMPLE } \\
\text { SIZE }\end{array}$ & $\begin{array}{l}\text { NUMBER } \\
\text { OF ALLELES }\end{array}$ & $\begin{array}{c}\text { AVERAGE } \\
\text { PAIRWISE } \\
\text { DIFFERENCE } \\
\text { AMONG } \\
\text { ALLELES (\%) }\end{array}$ & $\begin{array}{c}\text { PAIRWISE } \\
\text { SEQUENCE } \\
\text { DIFFERENCE } \\
(\%)(\text { RANGE) }\end{array}$ & $\begin{array}{l}\text { ALLELES FROM } \\
\text { (REFERENCE) }\end{array}$ \\
\hline $\begin{array}{l}\text { Guiana (Sotalia guianensis) and } \\
\text { Tucuxi dolphins (Sotalia fluviatilis)* }\end{array}$ & 33 & 4 & $6.7 \pm 0.014$ & $1.2-9.3$ & This study \\
\hline $\begin{array}{l}\text { Finless porpoise (Neophocaena } \\
\text { phocaenoides) }\end{array}$ & 50 & 8 & $2.4 \pm 0.008$ & $0.6-6$ & Hayashi et al, (2003) \\
\hline $\begin{array}{l}\text { Beluga } \\
\text { (Delphinapterus leucas) }\end{array}$ & 233 & 5 & $3.5 \pm 0.011$ & $0.6-6$ & Murray et al, (1995) \\
\hline $\begin{array}{l}\text { Antarctic minke whale } \\
\text { (Balaenoptera bonaerensis) }\end{array}$ & 11 & 6 & $6.9 \pm 0.014$ & $1.2-13.4$ & Hayashi et al, (2003) \\
\hline $\begin{array}{l}\text { Humpback whale (Megaptera } \\
\text { novaeangliae) }\end{array}$ & 35 & $22^{1}$ & $6.2 \pm 0.012$ & $0.6-11.9$ & Baker et al, (2006) \\
\hline
\end{tabular}

Sample size is expressed in number of individuals.

${ }^{1}$ Duplicated DQB loci

* The two species were considered together for this comparison since some alleles were shared between them

Table 4. Sample size, number of alleles, proportion of synonymous substitutions per synonymous site $\left(d_{s}\right)$, proportion of nonsynonymous substitutions per non-synonymous site $\left(d_{n}\right)$ and their ratio at the peptide-binding region (PBR), non-PBR and along the whole exon-2 sequence examined (171bp) of the DQB locus in various cetacean species.

\begin{tabular}{|c|c|c|c|c|c|c|c|c|c|c|c|c|}
\hline \multirow[t]{2}{*}{ SPECIES } & \multirow{2}{*}{$\begin{array}{l}\text { SAMPLE } \\
\text { SIZE }\end{array}$} & \multirow{2}{*}{$\begin{array}{l}\text { NUMBE } \\
\text { ROF } \\
\text { ALLELES }\end{array}$} & \multicolumn{3}{|c|}{ PBR } & \multicolumn{3}{|c|}{ NON-PBR } & \multicolumn{3}{|c|}{ WHOLE SEQUENCE } & \multirow{2}{*}{$\begin{array}{c}\text { ALLELES } \\
\text { FROM } \\
\text { (REFERENCE) }\end{array}$} \\
\hline & & & $d_{s}$ & $d_{n}$ & $\begin{array}{r}d_{n} / \\
d_{s} \\
\end{array}$ & $d_{s}$ & $d_{n}$ & $\begin{array}{r}d_{n} / \\
d_{s} \\
\end{array}$ & $d_{s}$ & $d_{n}$ & $\begin{array}{r}d_{n} / \\
d_{s} \\
\end{array}$ & \\
\hline $\begin{array}{l}\text { Guiana } \\
\text { (Sotalia } \\
\text { guianensis) } \\
\text { and Tucuxi } \\
\text { dolphins } \\
\text { (Sotalia } \\
\text { fluviatilis)* }\end{array}$ & 33 & 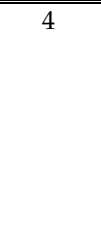 & $\begin{array}{c}0.055 \\
( \pm 0.067)\end{array}$ & $\begin{array}{c}0.228 \\
( \pm 0.055)\end{array}$ & 4.14 & $\begin{array}{c}0.033 \\
( \pm 0.025)\end{array}$ & $\begin{array}{c}0.043 \\
( \pm 0.021)\end{array}$ & 1.30 & $\begin{array}{c}0.038 \\
( \pm 0.022)\end{array}$ & $\begin{array}{c}0.086 \\
( \pm 0.022)\end{array}$ & 2.26 & This study \\
\hline $\begin{array}{l}\text { Finless } \\
\text { porpoise } \\
\text { (Neophocaena } \\
\text { phocaenoides) }\end{array}$ & 50 & 8 & $\begin{array}{l}0.00 \\
-\end{array}$ & $\begin{array}{c}0.071 \\
( \pm 0.026)\end{array}$ & - & $\begin{array}{l}0.00 \\
-\end{array}$ & $\begin{array}{c}0.020 \\
( \pm 0.012)\end{array}$ & - & $\begin{array}{c}0.00 \\
-\end{array}$ & $\begin{array}{c}0.033 \\
( \pm 0.011)\end{array}$ & - & $\begin{array}{l}\text { Hayashi et } \\
\text { al., (2003) }\end{array}$ \\
\hline $\begin{array}{l}\text { Beluga } \\
\text { (Delphinapter } \\
\text { us leucas) }\end{array}$ & 233 & 5 & $\begin{array}{l}0.00 \\
-\end{array}$ & $\begin{array}{c}0.117 \\
( \pm 0.048)\end{array}$ & - & $\begin{array}{c}0.013 \\
( \pm 0.010)\end{array}$ & $\begin{array}{l}0.024 \\
( \pm 1.5)\end{array}$ & 1.84 & $\begin{array}{c}0.0092 \\
( \pm 0.008)\end{array}$ & $\begin{array}{c}0.045 \\
( \pm 0.018)\end{array}$ & 4.89 & $\begin{array}{l}\text { Murray et al., } \\
\text { (1995) }\end{array}$ \\
\hline $\begin{array}{l}\text { Antarctic } \\
\text { minke whale } \\
\text { (Balaenoptera } \\
\text { bonaerensis) }\end{array}$ & 11 & 6 & $\begin{array}{c}0.017 \\
( \pm 0.011)\end{array}$ & $\begin{array}{c}0.185 \\
( \pm 0.043)\end{array}$ & 10.8 & $\begin{array}{c}0.042 \\
( \pm 0.018)\end{array}$ & $\begin{array}{l}0.056 \\
( \pm 2.5)\end{array}$ & 1.33 & $\begin{array}{c}0.035 \\
( \pm 0.014)\end{array}$ & $\begin{array}{c}0.085 \\
( \pm 0.023)\end{array}$ & 2.42 & $\begin{array}{l}\text { Hayashi et } \\
\text { al., (2003) }\end{array}$ \\
\hline $\begin{array}{l}\text { Humpback } \\
\text { whale } \\
\text { (Megaptera } \\
\text { novaeangliae) }\end{array}$ & 35 & 22 & $\begin{array}{c}0.025 \\
( \pm 0.021)\end{array}$ & $\begin{array}{c}0.166 \\
( \pm 0.047)\end{array}$ & 6.64 & $\begin{array}{c}0.046 \\
( \pm 0.019)\end{array}$ & $\begin{array}{l}0.041 \\
( \pm 1.5)\end{array}$ & 0.89 & $\begin{array}{c}0.040 \\
( \pm 0.015)\end{array}$ & $\begin{array}{c}0.069 \\
( \pm 0.018)\end{array}$ & 1.72 & $\begin{array}{l}\text { Baker et al., } \\
(2006)\end{array}$ \\
\hline
\end{tabular}

Standard error calculated by 1000 bootstrap replicates in parenthesis. Values in bold indicate $d_{n} / d_{s}$ with probability values rejecting the null hypothesis $d_{n}=d_{s}$ at a significance level of 0.05 (as published).

* The two species were considered together for this comparison since some alleles were shared between them 


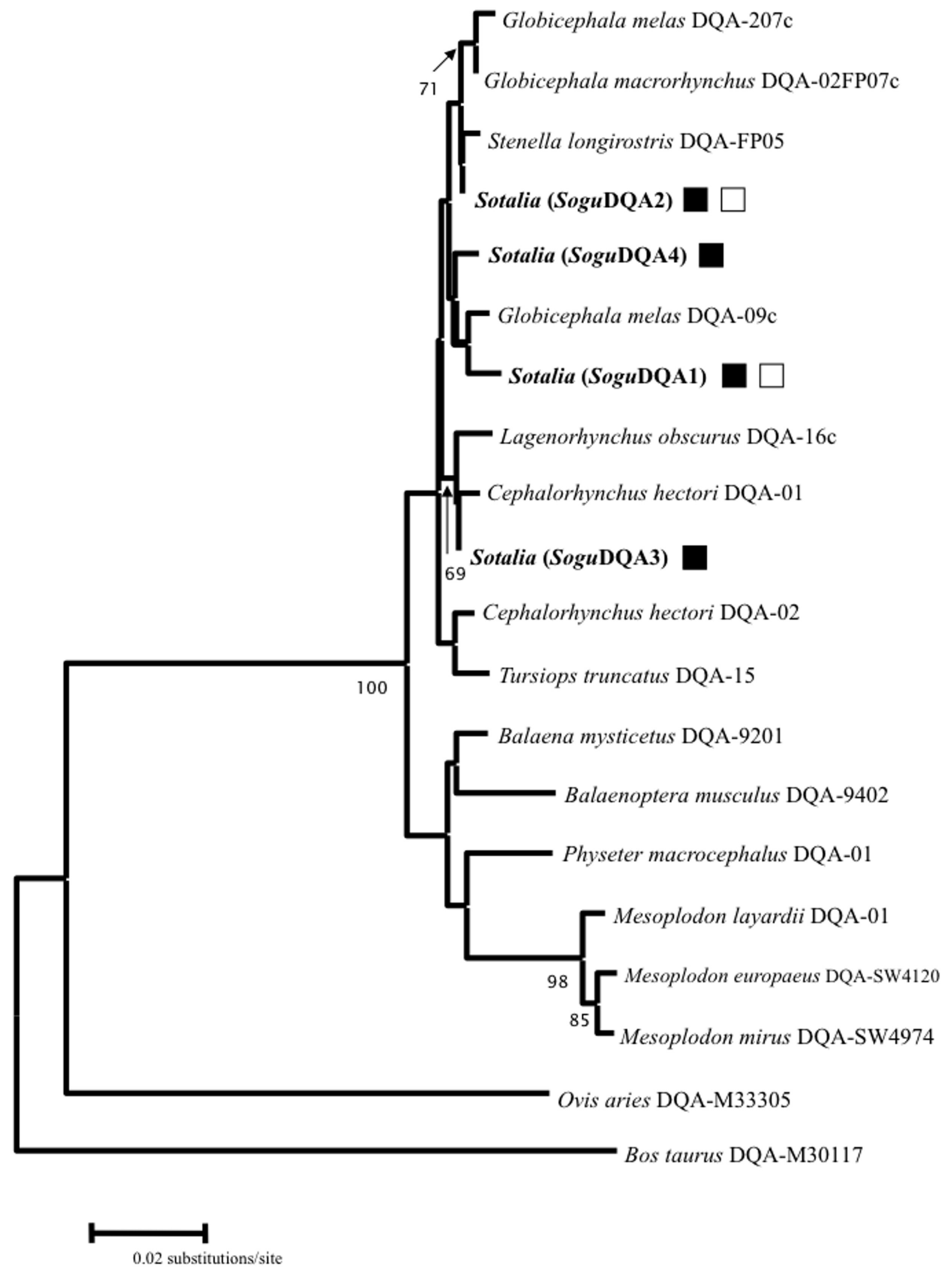

Figure 6. Neighbor-joining reconstruction of 309bp of Sotalia and selected unpublished cetacean DQA exon-2 exon-3 sequences (C.S. Baker, unpublished; Dalebout, 2002; Heimeier et al., 2009). DQA exon-2 exon-3 sequences from cow (Bos taurus) and sheep (Ovis aries) used as outgroups. Bootstrap support values (1000 replicates) higher than 60 are shown below the branches. Sotalia alleles are shown in bold. A black square represents alleles found in Sotalia guianensis and a white square represents alleles found in Sotalia fluviatilis. 
Table 5. DQA and DQB alleles found in particular coastal and riverine Sotalia population units (with sample sizes).

\begin{tabular}{|c|c|c|c|c|c|c|}
\hline \multirow[t]{3}{*}{ LOCUS } & \multirow[t]{3}{*}{$\begin{array}{l}\text { ALLELE } \\
\end{array}$} & \multicolumn{5}{|c|}{ SPECIES } \\
\hline & & \multicolumn{3}{|c|}{ Sotalia guianensis } & \multicolumn{2}{|c|}{ Sotalia fluviatilis } \\
\hline & & $\begin{array}{l}N S A \\
\mathrm{n}=12\end{array}$ & $\begin{array}{c}F G \\
\mathrm{n}=4\end{array}$ & $\begin{array}{c}B C \\
\mathrm{n}=10\end{array}$ & $\begin{array}{l}W A \\
\mathrm{n}=2\end{array}$ & $\begin{array}{c}E A \\
\mathrm{n}=5\end{array}$ \\
\hline \multirow[t]{6}{*}{ DQA } & SoguDQA1 & 目 & 司 & 蕒 & 国 & 囯 \\
\hline & SoguDQA2 & 蕞 & & 固 & 苗 & 蕒 \\
\hline & SoguDQA3 & & 氩 & 宔 & & \\
\hline & SoguDQA4 & & & 苜 & & \\
\hline & & NSA & $F G$ & $B C$ & $W A$ & $E A$ \\
\hline & & $\mathrm{n}=9$ & $\mathrm{n}=4$ & $\mathrm{n}=12$ & $\mathrm{n}=3$ & $\mathrm{n}=4$ \\
\hline \multirow[t]{4}{*}{ DQB } & SoguDQB01*01 & 䔰 & 罚 & 罚 & 䔰 & \\
\hline & SoguDQB02*01 & 罚 & & 圊 & & \\
\hline & SoguDQB03*01 & & & 固 & & \\
\hline & SoguDQB03*02 & 䑕 & & 㩁 & 富 & 眔 \\
\hline
\end{tabular}

The former study described very low variation in this MHC locus, with only two alleles determined in 110 Northern elephant seal samples (Weber et al., 2004). This low level of variation in this and other MHC locus in the northern elephant seal was explained by inbreeding after a severe population bottleneck. By comparison, the level of DQA allele variation was much higher in Sotalia, with four alleles determined in 33 samples. However, the average pairwise sequence difference among DQA alleles in Sotalia $(0.05 \%)$ was very similar to the nucleotide diversity of the two DQA alleles identified in the northern elephant seal (Weber et al., 2004).

The range of pairwise sequence difference within the four Sotalia DQB alleles (1.2-9.3\%) is much higher than within DQA alleles (0.03-0.09\%) or between nuclear introns for coastal and riverine species $(0.07 \%)$ (for more information refer to Caballero et al., 2007). It is also higher than pairwise sequence difference in the mitochondrial control region within each species (0.6$1 \%)$ and similar to the sequence difference in the mitochondrial control region between coastal and riverine species $(2.5 \%)$. This comparatively high pairwise sequence difference in the DQB locus is presumably related to balancing and diversifying selection acting to maintain diversity at this locus.

Evidence of positive selection was detected in the PBR region of the DQB exon-2 Sotalia alleles and this, as well, is similar to the results of other studies on cetacean DQB (Murray et al., 1995; Hayashi et al., 2003; Baker et al., 2006), and in other mammals [e.g. horses (Hedrick et al., 1999) and primates (Lukas et al., 2004; Schad et al., 2004)]. This result gives additional support to the important role of the DQB locus in cellular immune response in these organisms. The proportion of non-synonymous substitutions per non-synonymous site $\left(d_{n}\right)$ in the PBR of Sotalia DQB alleles was similar to the values reported in other cetacean species (Hayashi et al., 2003). It is important to note that the signal of positive selection accumulated in the $d_{n} / d_{\mathrm{s}}$ ratio should be interpreted with caution, as it might be difficult to distinguish between selection occurring at present or operating in the past (Garrigan and Hedrick, 2003). Also, our analysis considered the two Sotalia sister species together.

MHC VARIATION BETWEEN COASTAL AND RIVERINE SOTALIA AND ACROSS SOTALIA POPULATION UNITS

Two DQA and two DQB alleles were shared between riverine and coastal Sotalia and, to date, no allele was found exclusively in riverine samples, while two DQA and two DQB alleles were found only in coastal samples. Due to the small sample size, these exclusive alleles may also be found in riverine samples when more samples are analyzed. Overall, results of the analyses of DQA and DQB variation and between coastal and riverine Sotalia were consistent with the trans-species mode of evolution of the MHC, in which selection operates to conserve alleles for longer than the divergence times of sister-species or related species. However, sample size was small and the potential existence of unique alleles in the coastal or riverine species warrants further investigation. Balancing selection has conserved common alleles between species for more than $2 \mathrm{MY}$ (million years) in the two gorilla species, the mountain gorilla (Gorilla beringei beringei) and the western gorilla (Gorilla gorilla) (Lukas et al., 2004), for more than 1-1.5MY in the American bison (Bison bison) and domestic cattle (Bos taurus, Bos indicus) (Mikko et al., 1997), and for more than 1-1.2MY in riverine and coastal Sotalia given estimated divergence using the mtDNA (Caballero et al., 2007). 
The Brazilian Coast population unit had the highest number of DQA and DQB alleles. The Brazilian Coast population unit also had one allele for DQA and one allele for DQB that were not observed elsewhere. This result seems to indicate that no apparent reduction in DQA and DQB allele diversity and variation has occurred in this population unit. This is relevant, because this population unit had the lowest nucleotide and haplotype diversity for the mtDNA CR $(0.16 \%$ and $28 \%$ respectively) when compared with other Sotalia guianensis population units (see Caballero et al. 2010 this volume). The MHC variation presented here for this population unit, higher than the variation observed in the population unit with one of the highest nucleotide and haplotype diversities $(0.48 \%$ and $83 \%$ respectively) at the mitochondrial level (the Northern South America population unit, see Caballero et al. 2010 this volume), could indicate that balancing selection is either still acting or acted in the recent past in order to maintain polymorphism in these genes after a possible demographic reduction with posterior expansion, as has been observed in other species subject to founder events or demographic bottlenecks (Bernatchez and Landry, 2003; Aguilar et al., 2004; Lukas et al., 2004). Further investigation is warranted to consider the genetic structure and MHC polymorphism along the Brazilian Coast Sotalia guianensis population unit.

\section{Acknowledgements}

We are grateful to all the people and institutions that gave us access to samples for this study: students and researchers at Fundación Omacha (Colombia), R. Vieira (Oceanario Islas del Rosario, CEINER, Colombia), M. Ruíz-García (Universidad Javeriana, Colombia), F. Ospina-Navia (Acuario de Santa Marta, Colombia), S. Dussan, M. C. Rosso and N. Jiménez (UJTL, Colombia), B. de Toisy (KWATA, French Guiana), L. Flach (PUCMG, Brazil), IBAMA (Brazil), the Tissue and DNA archive of the Southwest Fisheries Science Centre (SWFSC), La Jolla, California (samples from S. guianensis) All Brazilian samples were collected with the government permit IBAMA 131/2004. This research was developed according to the special authorization for access to genetic resources in Brazil \# 03/2004 issued by IBAMA/CGEN. In Colombia, authorization was granted by Ministerio del Medio Ambiente, Vivienda y Desarrollo Territorial (Contrato de Acceso a Recursos Genéticos No. 001). Thanks especially to P. Lara (UFMG, Brazil) for help with the laboratory analysis in Brazil. Funding for fieldwork and laboratory analysis was provided by the New Zealand Marsden Fund (to C.S. Baker), a University of Auckland International Ph.D. Scholarship (to S. Caballero), Colciencias-LASPAU (to S. Caballero), a Cetacean Society International Grant-In-Aid (to S. Caballero and J. A. Vianna), Universidad de los Andes (Colombia), Universidad Javeriana (Colombia), Conselho Nacional de Pesquisas (CNPq-Brazil), The University of
Auckland Graduate Research Fund and private resources.

\section{References}

Aguilar, A., Roemer, G., Debenham, S., Binns, M., Garcelon, D. AND WAYNE, R.K. (2004) High MHC diversity mantained by balancing selection in an otherwise genetically monomorphic mammal. Proceedings of the National Academy of Sciences of the USA 101(10): 3490-3494. http:/ / dx.doi.org/10.1073/pnas.0306582101

Auffray, C., Lillie, J.W. AND Korman, A.J. (1987) Structure and expression of HLA-DQa and -DXa: interallelic alternate splicing of the HLA-DQa gene and functional splicing of the HLA-DXa gene using retroviral vector. Immunogenetics 26 (12): 63-73. http://dx.doi.org/10.1007/BF00345456

Baker, C.S., Slade, R.W., Bannister, J.L., Abernethy, R.B., Weinrich, W.T., LiEn, J., Urban, J., Corkeron, P., Calambokidis, J., Vaseuez, O. And Palumbi, S.R. (1994) Hierarchical structure of mitochondrial DNA gene flow among humpback whales Megaptera novaeangliae, world-wide. Molecular Ecology 3(4): 313327. http:/ / dx.doi.org/10.1111/j.1365-294X.1994.tb00071.x

BAKer, C.S., VANT, M.D., DALebout, M.L., Lento, G.M., O'BRIEN, S.J. AND YUHKI, N. (2006) Diversity and duplication of $D Q B$ and $D R B$-like genes of the MHC in baleen whales (Suborder: Mysticeti). Immunogenetics 58(4): 283-296. http://dx.doi.org/ $10.1007 /$ s00251-006-0080-y

Bernatchez, L. And Landry, C. (2003) MHC studies in nonmodel vertebrates: what have we learned about natural selection in 15 years. Journal of Evolutionary Biology 16(3): 363377. http://dx.doi.org/10.1046/j.1420-9101.2003.00531.x

Brown, J.H., Jardetzky, T.S., Gorga, J.C., Stern, L.J., Urban, R.G., Strominger, J.L. And Wiley, D.C. (1993) Threedimensional structure of the human class II histocompatibility antigen HLA-DRI. Nature 364(6432): 33-39. http:/ / dx.doi.org/ $10.1038 / 364033 \mathrm{a} 0$

Caballero, S., Trujillo, F., Vianna, J.A., Barrios-Garrido, H., Montiel, M.G., Beltrán-Pedreros, S., Marmontel, M., Santos, M.C., Rossi-Santos, M., Santos, F.R. and Baker, C.S. (2007) Taxonomic status of the genus Sotalia: species level ranking for 'tucuxi' (Sotalia fluviatilis) and 'costero' dolphins (Sotalia guianensis). Marine Mammal Science 23(2): 358-386. http://dx.doi.org/10.1111/j.1748-7692.2007.00110.x

Caballero, S., Trujillo, F, Vianna, J.A., Barrios-Garrido, H., Montiel, M.G., Beltrán-Pedreros, S., Marmontel, M., Santos, M.C.O., Rossi-Santos, M.R., SANTOS, F.R. And BAKer, C.S. (2010) Mitochondrial DNA diversity, differentiation and phylogeography of the South American riverine and coastal dolphins Sotalia fluviatilis and Sotalia guianensis. Latin American Journal of Aquatic Mammals 8(1-2):69-79. http://dx.doi.org/ 10.5597/lajam00155

Cunha, H.A., da Silva, V.M.F., Lailson-Brito, J.J., Santos, M.C.O., Flores, P.A.C., Martin, A.R., Azevedo, A.F., Fragoso, A.B.L., Zanelatto, R.C. And Solé-Cava, A.M. (2005) Riverine and marine ecotypes of Sotalia fluviatilis are different species. Marine Biology 148(2): 449-457. http://dx.doi.org/10.1007/ s00227-005-0078-2

Dalebout, M.L. (2002) Species identity, genetic diversity and molecular systematic relationships among the Ziphiidae (beaked whales). Ph.D. Thesis. The University of Auckland. Auckland, New Zealand. 598 pp. 
Dupanloup, I., Schneider, S. And Excoffier, L. (2002) A simulated annealing approach to define the genetic structure of populations. Molecular Ecology 11(12): 2571-2581. http://dx.doi.org/10.1046/j.1365-294X.2002.01650.x

Ellegren, H., MiKKo, S., Wallin, K. AND Andersson, L. (1996) Limited polymorphism at major histocompatibility complex (MHC) in the Swedish moose A. alces. Molecular Ecology 5(1): 3-9. http:/ / dx.doi.org/10.1111/j.1365-294X.1996.tb00286.x

EwING, B. AND GREen, P. (1998) Base-calling of automated sequencer traces using Phred. II. Error probabilities. Genome Research 8(3): 186-194. http://dx.doi.org/10.1101/gr.8.3.186

Ewing, B., Hillier, L., Wendl, M.C. And Green, P. (1998) Basecalling of automated sequencer traces using Phred. I. Accuracy assessment. Genome Research 8(3): 175-185. http:/ / dx.doi.org/ 10.1101/gr.8.3.175

Garrigan, D. AND Hedrick, P.H. (2003) Perspective: detecting adaptative molecular polymorphism: lessons from the MHC. Evolution 57(8): 1707-1722. http://dx.doi.org/10.1111/j.00143820.2003.tb00580.x

Hayashi, K., Nishida, S., Yoshida, H., Goto, M., Pastene, L.A. AND KOIKE, H. (2003) Sequence variation of the DQB allele in the cetacean MHC. Mammal Study 28(2): 89-96. http:// dx.doi.org/10.3106/mammalstudy.28.89

Hayashi, K., Yoshida, H., Nishida, S., Goto, M., Pastene, L.A., KANDA, N., BABA, Y. AND KolKE, H. (2006) Genetic variation of the MHC $D Q B$ locus in the finless porpoise (Neophocaena phocaenoides). Zoological Science 23(2): 147-153. http:/ / dx.doi.org/ 10.2108/zsj.23.147

Hedrick, P.W. (1994) Evolutionary genetics of the major histocompatibility complex. American Naturalist 143: 945-964. http://dx.doi.org/10.1086/285643

Hedrick, P.W., Parker, K.M., Miller, E.L. and Miller, P.S. (1999) Major histocompatibility complex variation in the endangered Przewalski's horse. Genetics 152: 1701-1710.

Heimeier, D., BaKer, C.S., Russell, K., Duignan, P.D., Hutt, A. AND Stone, G.S. (2009) Confirmed expression of MHC class I and class II genes in the New Zealand endemic Hector's dolphin (Cephalorhynchus hectori). Marine Mammal Science 25(1): 68-90. http://dx.doi.org/10.1111/j.1748-7692.2008.00244.x

Hughes, A.L. And NeI, M. (1989) Nucleotide substitutions at major histocompatibility complex class II loci: evidence for overdominant selection. Proceedings of the National Academy of Sciences of the USA 86(3): 958-962. http:/ / dx.doi.org/10.1073/ pnas.86.3.958

Hill, A.V.S., KwiatKowski, D., McMichael, A.J., Greenwood, B.M. AND BENNET, S. (1992) Maintenance of MHC polymorphism. Nature 355: 403. http://dx.doi.org/10.1038/355403a0

KLEIN, J. (1986) Natural History of the Major Histocompatibility Complex. Wiley, New York, NY.

Klein, J., Bontrop, R.E., Dawkins, R.L., Erlich, H.A., Gyllenstein, U.B., Heise, E.R., Jones, P.P., Parham, P., WAKELAND, E.K. AND WATKINS, D.I. (1990) Nomenclature for the major histocompatibility complexes of different species: a proposal. Immunogenetics 31(4): 217-219. http://dx.doi.org/ 10.1007/BF00204890

KLEIN, J. AND TAKAHATA, N. (1990) The major histocompatibility complex and the quest for origins. Immunological Reviews 113:

\section{5-25. http://dx.doi.org/10.1111/j.1600-065X.1990.tb00034.x}

Kobayashi, N., TAmURA, K. AND AotsuKa, T. (1999) PCR error and molecular population genetics. Biochemical Genetics 37(910): 317-321. http://dx.doi.org/10.1023/ A:1018759210666

KrÜtzen, M., Barré, L.M., Möller, L.M., Heithaus, M.R., Simms, C. AND SHerwin, W.B. (2002) A biopsy system for small cetaceans: darting success and wound healing in Tursiops spp. Marine Mammal Science 18(4): 863-878. http://dx.doi.org/ 10.1111/j.1748-7692.2002.tb01078.x

Kumar, S., Tamura, K. and NeI, M. (2004) MEGA3: integrated software for molecular evolutionary genetics analysis and sequence alignment. Briefings in Bioinformatics 5(2): 150-163. http:/ / dx.doi.org/10.1093/bib/5.2.150

Lehman, N., Decker, D.J. and Stewart, B.S. (2004) Divergent patterns of variation in major histocompatibility complex class II alleles among Antarctic pinnipeds. Journal of Mammalogy 85(6): 1215-1224. http://dx.doi.org/10.1644/BDW-010.1

Lukas, D., Bradley, B.J., Nsubuga, A.M., Doran-Sheeny, D., RoBBins, M.M. AND VIGILANT, L. (2004) Major histocompatibility complex and microsatellite variation in two populations of wild gorillas. Molecular Ecology 13(11): 3389-3402. http:/ / dx.doi.org/10.1111/j.1365-294X.2004.02353.x

MikKo, S., Spencer, M., Morris, B., Stabile, S., Basu, T., Stormont, C. AND ANDERSSON, L. (1997) A comparative analysis of MHC $D R B 3$ plymorphism in the American bison (Bison bison). Journal of Heredity 88(6): 499-503.

MølLER, A.P. (1998) Evidence of larger impact of parasites on hosts in the tropics: investment in immune function within and outside the tropics. Oikos 82(2): 265-270. http://dx.doi.org/ $10.2307 / 3546966$

Monteiro-Filho, E.L.A., Rabello-Monteiro, L. And Reis, S.F. (2002) Skull shape and size divergence in dolphins of the genus Sotalia: a morphometric tridimensional analysis. Journal of Mammalogy 83(1): 125-134. http://dx.doi.org/10.1644/15451542\%282002\%29083\%3C0125:SSASDI\%3E2.0.CO;2

Monteiro-Neto, C., Itavo, R.V. and Souza-Moraes, L.E. (2003) Concentrations of heavy metals in Sotalia fluviatilis. Environmental Pollution 123(2): 319-324. http://dx.doi.org/ $10.1016 /$ S0269-7491\%2802\%2900371-8

Murray, B.W., Michaud, R. and White, B.N. (1999) Allelic and haplotype variation of the major histocompatibility complex class II DRB1 and DQB loci in the St Lawrence beluga (Delphinapterus leucas). Molecular Ecology 8(7): 1127-1139. http:/ / dx.doi.org/10.1046/j.1365-294x.1999.00670.x

Murray, B.W., Molik, S. and White, B.N. (1995) Sequence variation at the major histocompatibility complex locus DQB in beluga whales (Delphinapterus leucas). Molecular Biology and Evolution 12(4): 582-593.

Nei, M. And Kumar, S. (2000) Molecular Evolution and Phylogenetics. Oxford University Press, Oxford, England.

O'BRIEN, S. AND EVERMANN, J.F. (1988) Interactive influence of infectious disease and genetic diversity in natural populations. Trends in Ecology and Evolution 3(10): 254-259. http:/ / dx.doi.org/10.1016/0169-5347\%2888\%2990058-4

Palumbi, S.R. (1996) Nucleic acids II: The polymerase chain reaction. Pages 205-247 in Hillis, D., Moritz, C. AND Mable, B.K. (Eds). Molecular Systematics. Sinauer Associates, Sunderland, MA. 
Penn, D.J., Damjanovich, K. and Potts, W.K. (2002) MHC heterozygosity confers a selective advantage against multiplestrain infections. Proceeding of the National Academy of Sciences of the USA 99(17): 11260-11264. http://dx.doi.org/10.1073/ pnas.162006499

Potts, W.K. And Slev, P.R. (1995) Pathogen-based models favoring MHC genetic diversity. Immunological Reviews 143(1): 181-197. http:/ / dx.doi.org/10.1111/j.1600-065X.1995.tb00675.x

Saiki, R.K., Gelfand, D.H., Stofell, S., Scharf, R., Higuchi, R., Horn, G.T., Mullis, K.B. and ERlich, H.A. (1988) Primerdirected enzymatic amplification of DNA with a thermostable DNA polymerase. Science 239(4839): 487-491. http:/ / dx.doi.org/10.1126/science. 2448875

SAMBroOK, J., Fritsch, E.F. AND Maniatis, T. (1989) Molecular cloning: a laboratory manual. Cold Spring Harbor Laboratory Press, New York, USA.

Schad, J., Sommer, S. ANd GANZHorn, J.U. (2004) MHC variability of a small lemur in the littoral forest fragments of southeastern Madagascar. Conservation Genetics 5(3): 299-309. http:/ /dx.doi.org/10.1023/B:COGE.0000031137.50239.d3

Seddon, J.M. and Baverstock, P.R. (1999) Variation on islands: major histocompatibility complex (MHC) polymorphism in the bush rat. Molecular Ecology 8(12): 2071-2079. http:/ /dx.doi.org/10.1046/j.1365-294x.1999.00822.x

Slade, R.W. (1992) Limited MHC polymorphism in the Southern elephant seal: implication for MHC evolution and marine mammal population biology. Proceedings of the Royal Society of London Series B - Biological Sciences 249(1325): 163171. http://dx.doi.org/10.1098/rspb.1992.0099

Trowsdale, J., Groves, V. And Arnason, A. (1989) Limited MHC polymorphism in whales. Immunogenetics 29(1): 19-24. http:/ / dx.doi.org/10.1007/BF02341609

Tsuji, K., Aizawa, M. and Sasazuki, T. (1992) HLA 1991: Proceedings of the eleventh international histocompatibility workshop and conference. Oxford University Press, Oxford, UK.

Weber, D.S., Stewart, B.S., Schienman, J. And Lehman, N. (2004) Major histocompatibility complex variation at three class II loci in the northern elephant seal. Molecular Ecology 13(3): 711718. http://dx.doi.org/10.1111/j.1365-294X.2004.02095.x

Wegner, K.M., Reusch, T.B.H. and Kalbe, M. (2003) Multiple parasites are driving major histocompatibility complex polymorphism in the wild. Journal of Evolutionary Biology 16(2): 224-232. http://dx.doi.org/10.1046/j.1420-9101.2003.00519.x

YANG, G., YAN, J., Zhou, K. AND WeI, F. (2005) Sequence variation and gene duplication at $\mathrm{MCH} D Q B$ loci of baiji (Lipotes vexillifer), a Chinese river dolphin. Journal of Heredity 96(4): 310-317. http://dx.doi.org/10.1093/jhered/esi055

YUHKI, N. AND O'BRIEN, S.J. (1990) DNA variation of the mammalian major histocompatibility complex reflects genomic diversity and population history. Proceedings of the National Academy of Sciences of the USA 87(2): 836-840. http:/ / dx.doi.org/ $10.1073 /$ pnas.87.2.836 
